\title{
Job analysis for a changing workplace
}

\author{
Parbudyal Singh *,1 \\ School of Administrative Studies, York University, 4700 Keele Street, Toronto, Ontario, Canada M3J 1P3
}

\section{A R T I C L E I N F O}

\section{Keywords:}

Strategic job analysis

Job analysis

Changing workplace

Competency modelling

\begin{abstract}
A B S T R A C T
Job analysis sits at the heart of all human resource practices, making it a critically important management activity in every organization. However, with increasing competition, shorter product life-cycles, rapid technological innovations, and the changing nature of organizational structures, its underlying assumptions are becoming increasingly questionable in today's dynamic work environment. Moreover, the methods used by traditional job analysis are simply not applicable to many new and emerging jobs and some authors feel it may even be an obstacle to organizational success. This has led to calls for a more proactive and strategic approach to job analysis so that the procedures will continue to be relevant. In this article, I emphasize the need for a strategic approach to job analysis, present a strategic job analysis framework, and discuss implications for organizations.
\end{abstract}

\section{Introduction}

Job analysis may be viewed as the hub of virtually all human resource management activities necessary for the successful functioning of organizations (Gael, 1988a; Mirabile, 1990; Oswald, 2003; Siddique, 2004). At the heart of almost every human resources management program or activity is the need for accurate and thorough job information. Job analysis is thus a prerequisite activity for the effective management of human resources. However, many important assumptions that underlie such fundamental uses of job analysis in management are becoming questionable in today's business environment. Job analysis is focussed on the collection of work-related information for the job as it currently exists and/or has existed in the past (Palmer \& Valet, 2001, Schneider \& Konz, 1989). Further, the procedures are related more to the situation of a one person-one job situation. Yet, as competition and technological innovations increase and product life cycles get shorter, jobs are becoming not only less static, but also less individually-based. Consequently, the tasks to be performed, and the knowledge, skills and abilities (KSAs) required for effective job performance are also becoming more volatile, and sometimes more team-based. Furthermore, and in all likelihood, organizations may perceive the creation of jobs that do not currently exist, the analysis of which is beyond the scope of traditional job analysis.

This has led to calls for a more proactive and strategic approach to job analysis, so that the procedures will continue to be relevant in today's workplace (Barnes-Nelson, 1996; Ethridge, Rodgers, \& Fabian, 2007; May, 1996; Morgan \& Smith, 1996; Sanchez, 1994; Schneider \& Konz, 1989; Siddique, 2004). However, research on such approaches is, to a large extent, lacking in the literature (notable exceptions include Schneider \& Konz, 1989; Sanchez, 1994; Siddique, 2004). As Guion (1993, p.487) states:

“...job analysis, as we generally know it, suffers from a couple of serious plagues, at least for inferring performance requirements. One of these is its emphasis on the status quo...we need further kinds of analysis to avoid the static nature of conventional job analysis. We need organizational forecasting information, strategic plans, and both current information and plans related to the interactions between different organizational activities."

\footnotetext{
* Tel.: +1 $4167362100 \times 30100$.

E-mail address: singhp@yorku.ca.

1 The author is grateful to Drs. Naresh Agarwal, Rick Hackett, John Medcof, and Willi Wiesner, McMaster University, and three anonymous reviewers for their comments. Special thanks to Nadia DeGama and Christine Thrussell, graduate students at York University, for their research assistance.
} 
Gatewood and Feild (1994, p.357) voice similar sentiments:

“...given the rapid technological changes that many organizations are experiencing, strategic job analysis or a similar approach is likely to become a necessity...clearly, more research on methods for identifying employee specifications of future jobs is an important need."

While there has been some debate and discussions on strategic job analysis, the need for such an approach is still evident a decade after these observations. In fact, the Society of Industrial and Organizational Psychology recently put together a Task Force to study the related issues of job analysis and competency modelling. In its report, the authors concluded that:

"in an era of unprecedented change in business and the way work is structured, when organizational leaders eagerly seek useful information they can use to drive decision making, it is fascinating that a useful tool like job analysis is widely viewed as mundane technical activity...perhaps it is time we updated our thinking of job analysis...specifically, the field of job analysis might benefit from paying a closer attention to the strategic and future-oriented needs of organizations. It is reasonable to conclude that decisions about the strategy and direction of an organization will have downstream implications for work roles and worker requirements...yet, there is virtually no research and very little description of practice" (Shippmann et al., 2000, pp. 732-733).

This paper is an attempt in helping to fill this apparent void in the research literature. More specifically, the objectives are: (i) to emphasize the need for a strategic approach to job analysis; and (ii) to propose a strategic job analysis framework that takes into consideration the needs of the changing workplace. This paper is organized into five main sections. Following this introduction, the second section offers a general overview of traditional job analysis: definitions, history, and importance/uses. The third section examines some of the assumptions of job analysis that do not hold in many contemporary organizations; the need for a strategic approach is established. The fourth part examines the sparse literature on strategic or similar approaches to job analysis and argues a case for a more strategic approach to job analysis, following which a framework for strategic job analysis is proposed, and some of its more important implications discussed. The conclusion summarizes the main arguments made in the paper and offers suggestions for future research.

\section{Traditional job analysis: an overview and re-evaluation}

\subsection{The nature of jobs}

Increasing attention is being focussed on the changing nature of the 'job' concept itself, with mention of such phenomena as the 'jobless' organization and 'de-jobbing'. It is thus useful to first examine the nature and substance of jobs. Ilgen and Hollenbeck (1991, p.173) define a job as "a set of task elements grouped together under one job title and designated to be performed by a single individual." However, a consensus seems to be developing that job boundaries are becoming blurred, as inter-job activities become the norm (Drucker, 1987; Sanchez, 1994; Shippmann et al., 2000). This has led many scholars to re-examine the ways 'jobs' are defined and modifications to the definition to make it more open to change. Such terms as "role" (Ilgen \& Hollenbeck, 1991; llgen, 1994) and "work" (Sanchez, 1994) have consequently been used as alternatives to the seemingly static and individualistic "jobs".

While there is some merit in such semantics, it seems evident that "jobs" will continue to be the dominant lexicon of the workplace well into the future. Thus, re-defining it to include work done by, or the role of, a single individual, as well as teams, may be the path to follow. As such, in this paper, the term "job analysis" is maintained over work-analysis or role-analysis.

\subsection{A brief historical overview}

The history of job analysis can be traced back to Socrates in the fifth century B.C. and his description of the ideal state (Primoff \& Fine, 1988). Apparently, Socrates was concerned with the work that needed to be done, and who did it, and this represented the conceptual beginnings for job analysis. It seems as if the first large scale job analysis was conducted by Diderot, an encyclopaedist (Primoff \& Fine, 1988). In 1747, whilst working on an encyclopaedia, he discovered that the jobs in the trades, arts, and crafts seemed incomplete and lacked a unified purpose. He consequently investigated the nature and content of these jobs and reorganized them into specific job categories.

However, the term job analysis did not appear in the managerial literature until early in the twentieth century. In 1916, Frederick Taylor referred to job analysis as the first of the four principles of scientific management (Ash, 1988). Taylor's job analysis procedure implicitly addressed efficiency aims in the selection, motivation, and training of the worker (Gael, 1988b; Primoff \& Fine, 1988). By 1922, the field had generated so much interest that one author (Uhrbrock) was able to write on the history of job analysis (Ash,1988). Industrial engineering also had a significant early impact on job analysis through the work of Frank and Lilian Gilbreth in the early part of the 20th century. In their efforts to increase productivity, they developed methods to study worker motions, and in doing so, examined jobs from the perspective of the elemental parts (Jeanneret, 1991). Job analysis methods have grown considerably since the early theoretical foundations and currently include, among others, the Position Analysis Questionnaire (PAQ), the Critical Incidents Technique, Fleishman's Job Analysis Survey, Functional Job Analysis, and the Job Element Method. Methodological variations are inherent in such a range of analytical approaches (for details, see Harvey, 1991; McCormick, 1976). 


\subsection{Uses/importance}

Job analysis has grown considerably in scope and applications, especially over the last few decades. By the 1950s, even though there seemed to be less academic publications than before, job analysis became an influential management tool in business and industry (Gatewood \& Feild, 1994; Ghorpade \& Atchison, 1980). However, by the 1970s, there was renewed academic interest, fuelled by an increasing need for current, accurate job data, a situation catalyzed by legal guidelines and court cases (e.g., Abermarle paper Co. v. Moody; Griggs v. Duke Power Co., etc.). The ratification of the Fairplay Overtime Initiative in August, 2004, provides a recent illustration of the importance of job analysis (Honoree, Wlyd, \& Juban, 2005).

Further, it became evident that job analysis was a sound business practice that can improve communication, accommodate change, contribute to improved human resource management, and be cost effective (Clifford, 1994; Levine, 1983; Prien, Prien, \& Wooten, 2003). There is hardly a program of interest to human resource specialists and other practitioners, whose work pertain to the interface between people and jobs, that does not depend or cannot benefit from the results of a good job analysis. An examination of the literature reveals that job analysis has provided an informational base for a wide variety of organizational and managerial functions, including among others, selection and staffing (Carless, 2007, Gatewood \& Feild, 1994; Jenkins \& Griffith, 2004; Schofield, 1993; Wernimont, 1988; Wilde, 1993), training and development (Campbell, 1989; Mitchell, Ruck, \& Driskill, 1988; Wooten, 1993), performance appraisal (Latham \& Fry, 1988), compensation and benefits (Henderson, 1988; Taber \& Peters, 1991; Weinberger, 1989), job descriptions and job design (Davis \& Wacker, 1988; Gael, 1988b, Konczak, 2007), and employment equity and affirmative action (Berwitz, 1988; Simola, Taggar, \& Smith, 2007; Thacker, 1990; Veres, Lahey, \& Buckly, 1987). It is therefore clearly evident that job analysis has been, and will continue to be, an extremely useful management tool. However, as with every other human resource management function or activity, rapid environmental changes have prompted timely calls for a re-examination and re-invention of traditional job analysis so that it can better serve the emerging needs of contemporary organizations.

\section{A re-examination of traditional job analysis}

\subsection{Assumptions of traditional job analysis and incompatibilities with the changing workplace}

One of the basic assumptions of traditional job analysis is that individuals, jobs and the match between them are stable over time (llgen, 1994; Sanchez, 1994; Schneider \& Konz, 1989; Snow \& Snell, 1993). As Schneider and Konz (1989, p.51) note, “...the implicit assumption has been that the specification of the tasks to be performed, and the knowledge, skills and abilities required for job performance are for a job as it currently exists, and/or has existed in the past. This assumption implies that the job is static..." Such stability was inherently tied to mass-production techniques, long product cycles, large market shares and scarce competition that typified the organizational environment about two or three decades ago. In addition to the assumption of stability, traditional job analysis also assumes that the job in question exists, and that you can literally observe incumbents performing related tasks, or get job-related through other sources such as surveys.

Further, traditional job analysis practices and methods were significantly influenced by the work of Frederick Taylor and the mass-production approach advocated by the scientific management movement (Ash, 1988; Sanchez, 1994). Jobs were broken down to its components and assigned to multiple workers, "scientific methods" were used to define one best way to perform a task, and management control was of paramount importance. The consequent division of labour and increased standardization were viewed as essential for high-volume production and economic efficiency. In this system, a worker was responsible for a specific part of the final product and was not encouraged to cross boundaries (Drucker, 1987; Young, 1992). As Sanchez (1994, p.55) states, "...jobs were seen as encapsulated entities with clear-cut boundaries. Observation of employees during the short cycle of their work routine was often sufficient to obtain an accurate picture of the job." Essentially, job analysis was focussed on the job, rather than inter-job activities and team-based work. The increasing use of teams in organizations further questions the utility of the traditional job analysis. Furthermore, Stewart and Carson (1997) assert that inherent to Taylor's scientific management approach is the idea that "organizations consist of positions (not employees). Jobs can therefore be conceptualized, analyzed, defined and discussed as meaningful entities separate from the people who either fulfil (incumbents) or who may fulfil (applicants) the requirements of a particular position" (p. 158).

The practice of "scientific management" also promoted the separation of employees into two distinctive categories: managers and workers. Those who did the core work were excluded from the management process and this widened the gap between labour and management. The resulting adversarial approach to industrial relations was, in part, responsible for the pre-determined, clearcut job boundaries and specific job descriptions. Many unions, in an effort to minimize management abuse, demanded clearly defined tasks for workers and discouraged them from performing tasks that were not in their job descriptions (McCune, Beatty \& Montagno, 1988; Sanchez, 1994). Further, management actively encouraged the development of job-analytic methodologies since these helped in other management functions such as employee selection, compensation and training. Thus, in the past, traditional job analysis represented a win-win situation for both management and unions.

These assumptions, and past conditions, no longer hold in most organizations today. Organizations are experiencing rapid changes that have reduced the stability of jobs and the KSAs required to perform specific tasks. Also, as Stewart \& Carson point out (1997, p. 158), "modern organizations are less often structured around jobs. Self-managing teams are replacing bureaucratic hierarchies". Further, organizations are creating jobs that never existed. They are also seeking more cooperative approaches to labour-management relations (Wiesendanger, 1994). In order to survive and thrive, these organizations must adapt to changing labour force demographics, global competition and increasing competition due to free-trade, innovations in technology, 
deregulation, and fast-evolving markets (Ariss, Rezvanian \& Mehdian, 2007; Landry, Mahesh, \& Hartman, 2005; Morgan \& Smith, 1996). If they want to succeed, an organization's HR practices need to constantly adapt to the rapidly changing environment.

In organizations characterized by such environmental turbulence, traditional job analysis is becoming increasingly obsolete. As May (1996, p.98) argues:

"The reality is, jobs can change rapidly and organizations need maximum flexibility. The more jobs change, the less value there is to gathering data that will need to be collected again in the near future. The shelf-life of job analysis results is only as long as the duration of the current job configurations. Thus, traditional job analysis practices are found lacking in light of changes in the nature of work, such as decreased specialization and shifting or shared work assignments."

Along similar lines, Catano, Cronshaw, Wiesner, Hackett and Methot (1997, p.168) argue that:

“...the evolution toward rapidly changing jobs and organizations that demand flexibility of their workers, suggests that the need for new approaches to job analysis is now an organizational reality."

It is becoming evident that many of the static and simplified jobs, developed through Taylorism, are unsuited to this dynamic business environment. Modern management techniques require cross-functionally competent employees not restricted to their own little worlds in the production process. Many researchers and practitioners accuse traditional job analysis of being too legalistic and of creating artificial boundaries that interfere with this emerging need for team-oriented and cross-functional employees (Campion, 1994; Drucker, 1987; Olian \& Rynes, 1992; Young, 1992).

Stewart and Carson (1997) state that the move from a manufacturing to service society may be one reason attributing to such a response. With an increase in service work, employees are taking on a wide range of roles and responsibilities, thus are constantly going beyond what is stated in their job descriptions. In addition, compared manufacturing work, jobs done in the service sector are difficult to examine objectively making traditional job analyses even harder to conduct.

Further, many organizations are rotating employees through a number of positions so as to enhance organizational flexibility. The tasks such employees are asked to perform are partly determined by specific need and such needs are often difficult to predict. These employees must therefore be adaptable, flexible, and multi-skilled. Such flexibilities are difficult to achieve using rigid jobanalytic techniques geared for an environment characterized by stability and scarce competition. Furthermore, people themselves may change making a stable person-job fit even more unlikely (Snow \& Snell, 1993). Stewart and Carson (1997) support this claim by asserting that traditional organizational structures rarely outline the numerous relationships held by employees. Examples of these relationships include work done through teams, as well as relationships individuals develop with their clients. An outcome of such flattening to an organization's structure has meant that "job boundaries are blurry and often non-existent" (Sanchez, 1994, p. 57). The organization may also become "boundaryless" where "competencies reside and are recognized throughout the workplace. When an individual has the skill to do a task, he or she is encouraged to do it, regardless of the title or position" (Nelson, 1997, p. 41).

Furthermore, the increased use of technology in the workplace has also been able to facilitate the growing trend in alternative work arrangements. According to Hammer and Barbera (1997) "as population demographics continue to change rapidly and organizations strive to compete globally, organizations are developing strategies to adapt to the needs of the workforce" (p. 29). As a result, more and more companies are implementing alternative work schedules into their firm-wide policies.

Traditional job analysis seems inappropriate in such an environment reflected in the foregoing. Siddique (2004) suggests a proactive approach to a job analysis. Similarly, Hammer and Barbera (1997, p. 31) argue that "a strategic job analysis must be conducted prior to implementing alternative work schedules" to answer questions related to the evolving workplace.

\subsection{The need for a strategic approach}

In such a changing environment, North American organizations, as others worldwide, are seeking new management techniques to enhance competitiveness. The cornerstone of such techniques lies in the ability of the organization to successfully predict, and consequently plan and live with change.

In the strategic management literature, many researchers have focussed on organizational change as a result of innovations in technology and increased competition, among other factors (Lund \& Hansen, 1986; Marjchzak \& Klein, 1987). It is argued that the effects of these technological and other changes will be universal and apply to all organizations. Research and practice also suggest that new knowledge, skills, and abilities will be required if jobs are to be effectively and efficiently performed in this dynamic environment (Voskuijl, 2005). As London (1988) notes, organizations and managers need to think about critical jobs for the future and what would have to be done to ensure that the right people, with the right KSAs, were available at the right time.

As such, Schneider and Konz (1989, p.52) argue that, if "change and human resource management is all about people working at jobs, then jobs need be $a$, if not, the, focus of strategic human resources management. Here the literature appears to be quite silent...precisely what kinds of people need to be recruited and selected and the kinds of training they should actually receive are not identified." The silence is indeed deafening. The literature abounds with strategic approaches to other human resource functions including, among others, strategic staffing (Denka, 1994), strategic compensation (Heneman, 2002; Lawler, 1984; Snell \& Dean, 1994; Weinberger, 2007), strategic appraisal (Moravec, Juliff \& Hesler, 1995), and strategic labour relations (Fossum, 1984; Kochan \& Weinstein, 1994). If we can validly predict changes in these functions and plan appropriate and acceptable responses, 
then we should certainly develop procedures that will help to predict and plan for changes in job analysis, since it serves as a base for all other functions.

\section{Strategic job analysis (SJA)}

\subsection{Previous SJA approaches}

Despite the obvious need for a strategic approach to job analysis, there have been just a few theoretical attempts in proposing SJA frameworks. In a seminal paper, Schneider and Konz (1989) build on traditional job-analytic approaches in what they term a "multi-method job analysis" procedure. There is nothing particularly unique in their eight step approach until the stage of collecting information about the future and revising tasks and KSAs in light of future expected changes. The eight stages identified are: 1 . collect information on the current job; 2 . specify job tasks and build task clusters; 3 . develop and administer task surveys; 4. conduct statistical analysis of task survey responses; 5 . conduct the knowledge, skills and abilities process; 6 . develop and administer the KSA surveys; 7. gather information about the future; and, 8. revise tasks and/or task clusters, and KSAs and/or KSA clusters in light of future changes.

Schneider and Konz (1989) suggest that subject matter experts (SMEs), including job incumbents, supervisors, managers and job analysts, be brought together in a workshop to discuss likely future changes. In the final stage, job requirements are reevaluated in light of the expected changes in the job. As the authors acknowledge, this job analysis method poses a number of questions, including: What is the validity of SMEs predictions of the future? Who are the most accurate judges of the future? Should more formal techniques be used by SMEs? Can the procedure be applied to jobs that do not yet exist?

According to Stewart and Carson (1997, p. 169) "this approach acknowledges the dynamic nature of work and illustrates how perceptions of current and future jobs may differ, but it still assumes that jobs can be analyzed independent of people". Despite practical and theoretical problems inherent in the approach, the attempt is certainly useful since it highlights the need for SJA and offers a method to reshape job analysis to suit the emerging needs of many contemporary organizations.

Snow and Snell (1993), in an essay on staffing as a whole, rather than job analysis per se, argue that new trends in the environment demand changes in many human resource management functions, and that "companies that respond quickly and appropriately to the staffing challenges presented by these trends will find that they can outperform competitors who are slower to develop a strong human resource planning and management function" (p.448). Three conceptual models that characterize the staffing process are presented. Model 1, using traditional job analysis, seeks to match individuals to specific, well-defined jobs and ignores the company's strategy. Model 2 views staffing as part of the overall strategic implementation process and is concerned with broadly defined jobs, as well as linkages between jobs. Model 3 suggests that the recruitment, assessment and selection of high-calibre individuals should be the foundation of strategy. In this model, staffing drives the formation of competitive strategy.

In Model 2, strategy supplements traditional job analysis as the basis of staffing and takes into account the company's relationship with the environment. Its effectiveness is defined by the company's accomplishment of its strategic goals rather than just the personjob match. Model 3 assumes shorter business cycles and rapid technological advances. In such an environment, Snow and Snell (1993, p.462) contend that "instead of staffing to develop a single set of core competencies, strategic capability is enhanced by developing a broad skill base for value creation. A broad skill base helps to prepare for an unpredictable and unforeseeable future." Criticisms of these models range from the assumptions of a static environment in Model 1, to the fact that Model 3 is more a philosophy than a practice. However, as the authors suggest, contingency studies need to be done to determine where these models are the most effective, especially Models 2 and 3. It is more of a question as to which strategy is right for which organization as manufacturing jobs have largely have remained static due to the nature of the work and the continued presence of unions.

In a study more directly related to job analysis, Sanchez (1994) argues that traditional job analysis is tailored to the principles of the scientific management approach which is becoming unsuited to emerging business needs. He, however, contends that "despite the obsolescence of the traditional conception of job analysis, many forms of work analysis can meaningfully contribute to business competitiveness," and that, "informed modification of current job analysis practices requires knowledge of the underlying assumptions that have rendered traditional job analysis obsolete" (p.52). Some of the underlying assumptions identified include: simplified and predetermined job responsibilities; an adversarial approach to labor-management relations; static jobs with stable KSA requirements; scarce competition and large market share; isolated work stations and minimum employee feedback; individualistic approach to employee selection; and, a hierarchical approach to employee selection.

Among his wide ranging recommendations, and of direct relevance to this paper, are those that relate to the reduction of future uncertainties in the environment, the use of "work analysis" for teamwork, and the alignment of job/work analysis and business strategy. These include: 1 . Develop scenarios to facilitate the process of evaluating future KSA demands; 2 . Forecast emerging critical occupations, listing primary KSA requirements by level and function, and attempt to identify changes in staffing patterns due to new KSA requirements; 3. Ask SMEs to predict potential technological and organizational changes; 4. Revise current KSA requirements in light of future changes (from Schneider \& Konz, 1989); 5. Ask incumbents to rate their respective task inventories on scales measuring the extent to which successful completion of the task requires cooperation with others (team-work); and, 6. Identify key organizational and external relationships necessary to carry responsibilities and consequent strategy-related KSAs (e.g., openness to innovation, personal influence, etc.).

To improve on the validity of future-oriented job analysis, he suggests that practitioners:

1. Check agreement among the SMEs, consult experts, and examine international trends to discard unlikely views of future work activities; and, 2. Use group techniques to effectively integrate diverse views about future KSA requirements. 
The premise of Sanchez's (1994) arguments "is that work analysis can meaningfully contribute to the management approaches urged by a dynamic environment. However, a shift in the course of conventional job analysis is imperative for such a contribution to take place" (p.70).

In a more recent article, Siddique (2004) provided an intriguing look into the positive impact a competency-focussed job analysis approach can have on a company's performance. In an earlier piece, Cronshaw (1998) contended that "competencies are better suited to the newer, more fluid organizational structures of the late 20th century" (p. 10). As we move further into the 21st century we see that this statement is just as applicable today. In order for organizations to become more strategic in terms of their job analysis, Siddique (2004) advises that there is a need to start looking into competencies as opposed to tasks and KSA's as seen in the traditional job analysis approach. This approach, adopted and extended in this paper, is a possible bridging of job analysis and competency modelling techniques, through the use of a strategic framework. It emphasizes adaptability, teamwork orientation and other similar characteristics of employees considered important for successful job performance. Other competencies include "interpersonal skills, conflict resolution skills, innovative thinking, flexibility, decision making ability and self motivation". The use of a competency approach is critical for organizations wishing to develop a strategic job analysis (Mirabile, 1990; Shippmann et al., 2000). Siddique (2004) argues that a proactive job analysis "can help a company in creating a proper infrastructure by defining the tasks to be performed as well as the timelines for performing them...A proactive job analysis also contributes to organizational performance by promoting positive job attitudes" (p. 221).

The common theme in all four approaches is the need for job analysis to become more proactive and strategically oriented to suit the emerging organizational needs catalyzed by a turbulent business environment. While many questions remain unanswered, such as the validity and reliability of the strategic job analysis (Dierdorff \& Wilson, 2005; Prien et al., 2003), many of the timely issues raised can help in the development of a framework for strategic job analysis.

\subsection{A proposed framework}

It is generally agreed that various human resources functions should be integrated into the overall strategic management process of the organization (Boxall \& Purcell, 2000; Fisher, 1989; Meshoulam \& Baird, 1987; Tichy, 1985). Once a strategic direction for the organization is chosen, human resource practitioners have a crucial role in designing and developing human resources management systems that will aid in successful strategy implementation (Colbert, 2004; Cooke \& Armstrong, 1990; Dyer, 1985; Foulkes, 1986; Kydd \& Oppenheim, 1990; Lengnick-Hall \& Lengnick-Hall, 1988; Pffefer, 1994; Schuler \& Jackson, 1987; Wright \& Snell, 1998; Wright \& McMahan, 1992; Wright \& Snell, 1991)). One such system/function is the strategic job analysis, which, for the purposes of this paper, can be viewed as job analytic methods which help management anticipate and manage change relating to jobs and work. Thus, strategic job analysis means aligning current and future jobs with the strategic orientation of the organization. That is, SJA is a purposeful, systematic process of collecting current and future work-related aspects of a job, within the organization's strategic context.

As mentioned before, job analysis plays a pivotal role within the human resources management field, and is of crucial importance to other functions such as training, compensation and performance appraisal. As such, strategic job analysis should not only be integrally linked to the strategic management process of the organization, but to other related organizational functions as well. The strategic job analysis process, with some of its vertical and horizontal links, is illustrated in Fig. 1.

\subsubsection{Environmental analysis/job scan}

Unlike other "strategic" job analysis approaches, it is contended, in this paper, that the first step should be a systematic analysis of the operational environment of the organization, a position which coincides with that of many researchers and practitioners in the strategic management school (e.g., Ansoff, 1990; Camuffo and Costa, 1993; Porter, 1980; Walker, 1992). This signifies not just an ad hoc, but a fundamentally strategic approach to job analysis that is built into the organizational strategic management process. That is, regardless of the stability of the environment, or whether the job is individually- or team-based, or whether the job exists or not, the approach is proactive and strategic.

An environmental analysis/assessment entails the purposeful scanning of an organization's internal and external realms for information on opportunities, threats and probable changes. Basically, it is a fact-gathering exercise in which data on future trends

Environmental Analysis/ Job Scan<smiles>[3H][3H]</smiles>

A Focussed Internal Analysis/ Analyze Current Jobs<smiles>[13CH3]</smiles>

Determine and Prepare for Future Jobs/ Selection and Staffing (and other HR functions)

Evaluate the Effectiveness/Establish Validity

Fig. 1. The strategic job analysis process (and its strategic links). 
and changes are collected and examined. This activity may be integrated with the environmental analysis conducted for the organization's overall strategy formulation, or it may be conducted specifically for job analysis keeping in mind the strategic orientation of the organization.

An integral aspect of environmental analysis is the environmental scan which can be defined as "a process of systematic surveillance and interpretation designed to identify relevant events and conditions" (Schrenk, 1988, p.88). Environmental scanning provides a rational basis for action by anticipating future conditions. Forecasting is an integral part of the process and includes a wide variety of processes such as the Delphi method for combining expert opinion (Linstone \& Turoff, 1975), the creation of alternative scenarios (Manzini \& Gridley, 1986), and the use of forecasting models (Beatty, Coleman, \& Schneier, 1988; Sheridan, 1990).

Interestingly, Schneider and Konz (1989) and Sanchez (1994), in their approaches to strategic job/work analysis, advocate the use of subject matter experts (SMEs) in predicting future job changes. This is indeed an extremely useful exercise that may involve many participants within the company, as well as consultants and others. Schneider and Konz (1989, p.53) suggest that information on future changes can be "accomplished in a workshop composed of subject matter experts (e.g., job incumbents, supervisors, managers, human resources staff, strategic planners) and job analysts. The participants might also include experts in relevant technical fields, economists, demographers, and so forth, depending on the strategic job of interest." More recently this idea was reinforced by Brannick and Levine (2002) who suggest using expert panels as they "provide information quickly and relatively cheaply compared to large samples responding to task inventories or other structured questionnaires" (p. 317). Along similar lines, Sanchez (1994) suggests that SMEs be asked to describe "a day in their job of the future", taking into account potential technological and organizational changes. In an interesting article, Sanchez and Levine (1999) take this idea one step further and propose that when SMEs are picturing themselves perform their jobs in the future, to ask what and how will this be different?

Another way to identify the nature and dynamics of future jobs is to generate scenarios of possible future events. A scenario can be described as "a documented narrative of anticipated conditions that the organization expects to deal with at some time in the future" (Manzini and Gridley, 1986, p.94). Scenarios help the organization in generating strategies to deal with contingencies. The scenario integrates analysis of environmental trends, organizational objectives and human resource demand and availability. Ultimately, a good scenario should help to forecast personnel requirements and formulate plans (London, 1988). These requirements include the KSAs necessary to effectively perform future jobs.

Forecasting models can also be used to predict future changes in the nature and structure of jobs. Most of these models are complex and require significant amounts of historical data and statistical routines. Some of the most common modelling techniques include regression, econometric and simulation models. Each of these techniques can be used to predict future job changes and help in the determination of the KSAs required for effective performance, thus providing input to management regarding the direction of the business (Sheridan, 1990).

It is significant to note that the environmental scanning methodology described in this section "has been tested in practice and found effective in HRM applications" (Schrenk, 1988, p.88). These methods should not be confused with prophesy and forecasting based on individual or intuitive knowledge, which as forecasting techniques, lack credibility. Environmental scanning has grown in importance amidst rapid environmental changes and as Bassman (1990, p.29) asserts "the most forward-looking and strategically well-integrated companies have done this all along."

\subsubsection{Analyze current jobs - a focussed internal analysis}

This step is very similar to the traditional job analysis and does not need much elaboration. Basically, work-related information, which can be collected through a variety of methods, is analyzed and used to determine KSAs necessary for effective performance of the job as it exists. However, it is important to address the issue of job analysis for team-based work since this has not received considerable attention in the literature due, in part, to the fact that it is a relatively recent North American phenomenon.

4.2.2.1. Job analysis for teams. In the analysis of current jobs, rather than looking solely at within-job activities, we also need to look at the wider perspective that integrates inter-job activities, as well as teamwork into the analysis. Organizing employees into work teams is becoming an extremely popular management strategy (Swezney \& Salas, 1992; Jones \& Schilling, 2000). However, Sanchez (1994) contends that with vertical enlargement and horizontal enrichment jobs have become highly dependant on one another, making teamwork a necessity, and as Brannick and Levine (2002) predict, "work in the future will be accomplished by small teams of people who have rather flexible, dynamic jobs" (p. 150). One of the main features of organizing work around teams is that task responsibilities are mapped onto teams rather than onto individual persons who comprise the teams. Although individuals are still responsible for getting tasks done, these tasks are not allocated to specific individuals in a formal sense. Team members are expected, over time, to learn multiple tasks and to fill in for others when necessary. Brannick and Levine (2002) argue that given the difficulty in analyzing specific tasks to infer the required KSAs, one solution to the problem is to select people for generic traits that are valuable for a range of jobs. Further, Campion (1994) contends that attention needs to be focussed on KSAs required for the team-oriented situation itself and should include such skills as task coordination, participation, conflict resolution, problem-solving and communication. Along similar lines, Sanchez (1994) suggests that organizational citizenship, cooperation, and customer orientation behaviours be considered pertinent. As such, it is apparent that in conducting job analysis for teams, the focus should be on worker-oriented approaches, in which broad behaviours are identified.

Nevertheless, Brannick and Levine (2002) contend that the KSA approach mentioned above is only one method to analyzing the work of teams. Similar to the KSA approach, the team functions approach does not simply analyze the specific task content, rather it examines "universally required" functions that teams perform to achieve their goals, namely orientation, resource distribution, 
timing, coordination, and motivational functions (Nieva, Fleishman, \& Reick, 1978; Brannick \& Levine, 2002). While the KSA approach and teams function approach may have inherent differences, a central theme behind both is their emphasis on using generic descriptors for analyzing the work of teams.

\subsubsection{Determine and prepare for future jobs/conduct a "gap analysis"}

At this stage, the present and most likely future situations are compared by SMEs, job analysts and relevant personnel within the organization. Such a comparison allows an assessment of the extent to which changes in the environment of the organization yield significant task and KSA changes for the job in question. This comparison, or gap analysis, will reveal one of three possibilities: little or no significant differences, moderate differences, or significant differences.

These outcomes require different strategic responses and have implications for job analysis methodology, whether team- or individual-based. Organizations in relatively stable environments will, most likely, find that little or no significant differences result from the gap analysis. Organizations in such a situation may choose, at least in the short term, a "do nothing" strategy. Such a strategy has some utility. As Mintzberg (1987, p.76) notes, "managing strategy is mostly managing stability, not change...obsession with change is dysfunctional. Organizations that reassess their strategies continuously are like individuals who reassess their jobs or marriages continuously - in both cases people will drive themselves crazy or reduce themselves to inaction." The bottom line of his argument implied that the organization has to be able to sense when to change. It is thus evident that in relatively stable business environments, even though a strategic approach is taken in analyzing jobs, the KSAs required for effective job performance will be mostly guided by results from conventional job analysis.

When the outcome of the gap analysis shows moderate differences between the present and the future, the organization can take iterative steps in ensuring that jobs are continuously redesigned to keep apace with changes in technology and other environmental change factors. This implies that jobs should be redesigned, through conventional job analytic techniques, as reasonably certain information becomes available. As Cronshaw and Schalm (1995) suggest, "soft" people skills, such as working with high-involvement teams, can be built into a job on a long-term basis, whereas more specific technical skills can be built into the job only when that technology is close to adoption by the organization.

However, this gives rise to a paradox: if an organization waits until information is adequate before making a decisive response it will increasingly face crises; yet, if it accepts vague information, the response will lack adequate analysis. As such, some scholars have argued that instead of waiting for sufficient information to accumulate, a firm should determine what progressive steps are feasible and act more proactive as strategic information becomes available (Ansoff, 1990; Eppink, 1978; Harrigan, 1985; Mintroff, 1987; Porter, 1985; Rice, OConnor, \& Pierantozzi, 2008).

Significant differences between the present and predicted future states imply either rapid changes to current jobs or the creation of jobs that do not exist. Cronshaw (1998) asks "can job analysis be used to describe a "job" that isn't there yet (strategic job analysis)?" In such instances, SMEs may be used to define behaviours, and consequent KSAs, required for effective performance of a job as it is predicted to exist in the future. Fig. 2 illustrates this process and its link to human resource management (HRM) functions.

A few significant differences from the traditional approach are evident. Of particular interest is the fact that after future jobs are predicted, SMEs determine broad work behaviours, rather than specific tasks and functions. Further, these behaviours are best ensured through an emphasis on broad knowledge and skills, and enduring abilities.

\subsubsection{Evaluate effectiveness/establish validity of procedures}

Over time, the effectiveness of SJA must be evaluated on a continuous basis. One such way is to assess the "correctness" of the derived employee specifications through regular assessments of related activities, such as selection and performance appraisal. Such evaluations can also indicate the predictive/criterion-related validity of tools linked to SJA. Considering SJA is extremely significant in an organization's selection, training, performance evaluation, and compensation, it is critical that the criterion

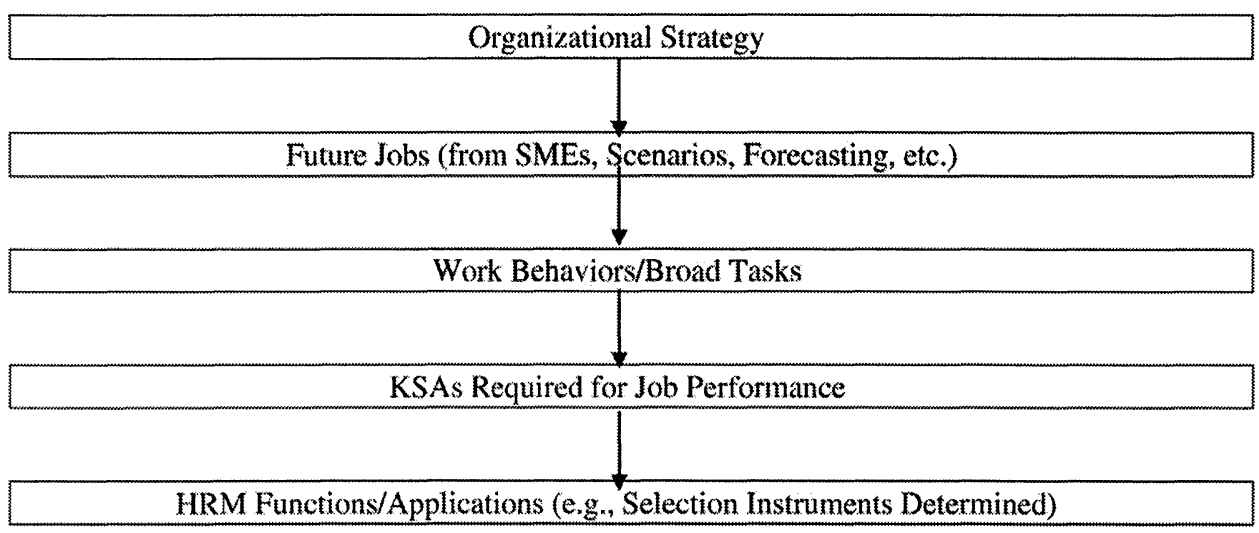

Fig. 2. SJA for jobs that do not exist or those rapidly changing. 
measures are relevant, and free from any deficiencies or contamination. The use of SMEs could potentially be problematic as a recent study by Dierdorff and Wilson (2005) revealed that "raters do in fact differ" resulting in rating variance (p. 643). While Sanchez and Levine (2000, p. 811) argue that such "SME disagreement feeds scepticism about the quality of JA data", Harvey and Wilson (2000) argue that SMEs help to ensure the accuracy of job analysis; in fact, they offer evidence that SMEs/experienced job analysts provide superior job analysis ratings over other sources (Harvey \& Wilson, 2000).

\subsection{An example of linking job analysis to an organization's strategy}

In order for job analyses to actually become strategic it is necessary to link the process to the strategic direction of the organization. Using Miles and Snow's (1978) strategic typology, this section of the paper will examine how an organization's strategic choice can impact the approach used in job analysis. Miles and Snow (1978) identify three organizational strategic types: defenders, prospectors and analyzers. According to Miles, Snow, Meyer, and Coleman (1978), "each type has its own unique strategy for relating to its chosen market(s), and each has a particular configuration of technology, structure, and process that is consistent with its market strategy" (p. 550). Miles and Snow (1978) also identified a fourth type of organizational strategy called the reactor. Unlike the other three strategic types, the academic literature does not focus their attention on 'reactor' organizations. A reason attributing to this may be due to the fact that reactors are considered as "failures" due to "inconsistencies existing among its strategy, technology, structure, and process" (Miles et al., 1978, p. 550).

Defender and prospector organizations can be seen as two points on opposite ends of a spectrum. Much of the academic literature juxtaposes them, while the analyzer type organization is nicely placed in a middle of the continuum, representing a combination of these two extremes. For this reason, the paper shall only focus defender and prospector strategic types, and the links these may have on an organization's job analysis.

\subsubsection{Defenders}

The central theme behind defenders is stability (Miles et al., 1978). By offering "limited product lines; single capital intensive technology; a functional structure; and skills in production efficiency, process engineering, and cost control" defenders set up the necessary conditions to ensure that they compete in a stable environment (Ragburam \& Arvey, 1994, p.56).

In addition, organizations with a defender business strategy are likely to adopt a long term perspective; maintain internal stability; have an extensive division of labour with an emphasis on skill specialization, and recruit and train staff for narrow skills (Ragburam \& Arvey, 1994). A traditional approach to job analysis may be more applicable for firms using a defender strategy, as jobs are considered stable over time. Miles et al. (1978) also state that the defender's adherence to strict controls and emphasis on a topdown management approach can also be seen as being highly mechanistic. This closely mirrors that of Taylor's "scientific management", a situation that spawned traditional job analysis.

\subsubsection{Prospectors}

According to Miles et al (1978), "unlike the Defender, whose success comes primarily from efficiently serving a stable domain, the Prospector's prime capability is that of finding and exploiting new product and market opportunities" (p. 551). These types of organizations are seen as innovators and change agents. In contrast to defenders, prospectors have a decentralized structure, low formalization, skill flexibility, and staff and train for broad skills (Ragburam \& Arvey, 1994). Based on these characteristics, organizations adopting a prospector style approach are ideal candidates for using a strategic job analysis approach. The prospector's use of flexible and broad skills complements the key ideas behind strategic job analysis due to its emphasis on generic content of jobs or work, empowerment, move to work teams, and multi-skilling (Cronshaw, 1998). As Schneider and Konz's (1989) asserted, "the goal of strategic job analysis is specification of the tasks to be performed and the knowledge, skills, and abilities (KSAs) required for effective performance for a job as it is predicted to exist in the future" (p. 53). This description is extremely fitting to a prospector as such organizations operate and thrive on rapid change and intense speed.

\section{Implications of strategic job analysis}

One of the major implications of strategic job analysis relates to the validity of the instruments/tools and processes that are spawned from it and the associated legal ramifications. It is evident that most of the North American legal guidelines and court cases that relate to human resource functions, especially selection and staffing, have been influenced by traditional job analysis (Harvey, 1991; Sparks, 1988). In the United States, the Civil Rights Act of 1964 and as amended in 1991, the Uniform Guidelines on Employee Selection Procedures (1978), and a number of precedent-setting court cases (e.g., Abermarle Paper Co. v. Moody; Griggs v. Duke Power Co., Wards Cove Packing Co. v. Antonio) have all established the need for organizations to do a thorough job analysis so as to avoid charges of discrimination (the situation in Canada is, on the whole, very similar to that in the United States). The generally accepted strategy for doing this is to ensure excellent psychometric properties of the selection and other HR tools, using appropriate validity studies. This raises one of the key concerns about strategic job analysis: How valid are the predictions of SMEs? Can SJA withstand the scrutiny of the courts and quasi-legal bodies, if challenged?

In addressing this issue, it is important to note that the courts have always considered business necessity when making decisions. With reference to a number of court cases (such as Spurlock v. United Airlines; Hodgson v. Greyhound Lines Inc.), Hills (1981) argues that business necessity can be sufficient defence in the event of discriminatory charges and that "under certain 
circumstances, an organization's belief that the selection device is job related may be sufficient. The condition under which this would seem appropriate is when the job in question goes to the essence of the business" (p.147).

Further, in a provocative analysis, Varca and Pattison (1993, p.225) state that:

"Arguably, validity research efforts in the 1970s and 1980s were driven not only by a desire to increase decision accuracy, but by a fear of litigation. Personnel researchers, particularly those in large organizations, had to be concerned that their validation projects met current business necessity standards. We might even argue that approaches to validity research and advances in this area have lingered under the prophylactic effect of precedents...that is, the protective cover offered by following proven strategies may have reduced the desire by researchers to cross open ground. The challenge now is that the courts are taking a flexible view of business necessity, and may be willing to listen to new methods for developing morally and technically sound employment systems."

The job analysis procedure proposed in this paper is a technically sound system; it is also face- and content-valid. Yet, it may be endangered by a narrow interpretation of current employment legislation or by blind adherence to traditional job analysis. However, as society learns to accept more proactive and strategic approaches to management dictated by new environmental forces, one would expect a parallel change in the courts' interpretation of existing employment law, or perhaps legislators may ponder changing those laws to give even more clout to business necessity. Organizations have normally protected themselves against costly litigation in discrimination cases by demonstrating a bona fide occupational qualification or by showing a business necessity. By using suitable defences such as a strategic or competency job analysis, an organization can outline its hiring process and defend its decisions against costly litigations and payouts to unqualified individuals.

The courts have not pronounced it illegal if employers use different evaluation and management techniques once the intent is not to discriminate and that these systems must also protect against systemic discrimination. For instance, in a 1999 case (Chavez $v$. Coors Brewing Company, US Ct of Appeals, 10 Circuit, \#98-1109), Chavez sued on the grounds of violating Title VII of the Civil Rights Act due to his race (Hispanic). The court ruled:

Notwithstanding any other provision...., it shall not be an unlawful employment practice for an employer to apply different standards of compensation, or different terms, conditions, or privileges of employment pursuant to a bona fide seniority or merit system...provided that such differences are not the result of an intention to discriminate because of race, color, religion, sex, or national origin, nor shall it be an unlawful employment practice for an employer to give and act upon the results of any professionally developed ability test provided that such test, its administrations or action upon the results is not designed, intended or used to discriminate because of race, color, religion, sex, or national origin.

Clearly, the intent of the strategic job analysis approach is not to discriminate; rather, it is a systematic job analytic process that the courts seem to accept.

Another implication of SJA also relates to selection and staffing. SJA, as described in this paper, goes beyond the traditional person-job match and implies the incorporation of KSAs and work behaviours aligned with the strategic thrust of the organization. Traditional job analysis infers KSAs solely from work behaviours associated with the current job. However, as Sanchez (1994, p.66) asserts, inferring KSAs "from formally prescribed work behaviours seems no longer sufficient because strategic competencies are often only indirectly linked to formal tasks." In addition, "the traditional staffing approach is consistent with hierarchical and mechanistic organizations" (Stewart \& Carson, 1997, p. 158). As we move to an economy in which organizations are less hierarchical; organic; and even boundaryless, a SJA approach may be more applicable. Under strategic selection and staffing, KSAs determination needs to go beyond traditional requirements by incorporating KSAs, including team-work skills, and behaviours that "fit" with the organization's strategy. For instance, Carson and Stewart (1996) suggest that adaptability and trainability; and self-motivation may be two factors underlying performance in team-based organizations. While they assert this is an area that deserves more research, they are two constructs that are worth examining when selecting and staffing individuals.

However, such a strategic orientation may pose a few problems. Firstly, there are concerns that too much "fit" will inhibit the organization's ability to change strategies and elicit new employee behaviours when the environment changes. As Evans (1986, p.158) contends, "the tighter the fit, the tighter is the interlock between elements, so the more rigid or inflexible is the system...the machine-like order symbolized by the concept of it is the enemy of innovations, flexibility, and adaptation." Further, adopting a set of human resources strategies consistent with the organization's strategy may ignore the realities of the labour market (this assumes that the organization's strategy does not take into consideration labour market realities). Competitors in the market may be pursuing different, perhaps better, human resources strategies. As such, "strategically sensible policies may need to be tempered by the reality of what it takes to attract and keep good employees in a particular labour market" (Fisher, 1989, p.160). Organizations should therefore strive for a "loose fit" and hire more adaptable, creative and highly motivated employees who can be trained to "fit" as the environment changes (Kerr \& Jackofsky, 1989).

It is evident that basic KSAs pertinent to the occupation will continue to be important; however, specific or specialized skills will be the most susceptible to change. As a consequence, it is argued that employers should focus on more enduring abilities, such as adaptability or flexibility, ability to handle ambiguity and stress, ability to learn (and relearn), creativity and problem-solving abilities, and ability to work cooperatively with peers (Wiesner, 1992). 
The creation of a broad skill base and a focus on more enduring abilities will enhance the flexibility and adaptability of employees in an organization so that they can better "fit" changing environments and strategies; this will in turn enhance the flexibility and adaptability of the organization itself. The human resource function, through a strategic job analysis, can help to ensure such attributes and in the process, increase the likelihood of the organization's survival and success. It is only after a comparison of current and possible future jobs that the organization can set its strategic job analysis objectives. The objectives should also take into consideration the overall strategic thrust of the organization. The objectives will guide the development of SJA action plans/programs and the allocation of resources. The SJA process must also be continuously evaluated through such feedback mechanisms as employee adaptation and performance.

\section{Conclusions}

Job analysis has always been, and will continue to be in the foreseeable future, a valuable informational tool in human resource management. Strategic job analysis, as proposed in this paper, is a necessary step in the evolution of traditional job analysis so that it can meaningfully tackle the emerging needs of contemporary organizations. Based on evidence presented in this paper, it is clear that organizations need to allow for considerable flexibility in their job analysis to accommodate for rapid changes in today's workplace. As a result, job analysis should incorporate general and broad traits instead of specific skills and behaviours. In addition, a job analysis that is strategic in focus is also proactive in that organizations are always monitoring and updating themselves to allow for such changes in the environment. Even though this paper addressed some of the concerns of previous SJA approaches, considerable more research is needed in the field. Firstly, there is evidently a major question about the accuracy and validity of SME predictions. To address such concerns, there is a need for research methodologies that combine the subjectivity of SME predictions and scenarios, and the objectivity of the statistical techniques. Creative methods can also be developed since, as this paper has implied, the frontiers of validity research may be less precarious. There is also a need for research on SJA efforts by practitioners and others. What methodologies were used? Can we integrate these approaches with the theoretical framework proposed in this paper? The SJA methodology, at this infant stage, will perhaps be flawed in certain areas. However, given the stakes and the circumstances, there may be no other credible alternative. While the costs of inaccurate or unreliable SJA predictions may be high, the costs of not trying would certainly be higher.

\section{References}

Ansoff, H. (1990). Implanting strategic management. New Jersey: Prentice-Hall.

Ariss, R. T., Rezvanian, R., \& Mehdian, S. M. (2007). Cost efficiency, technological progress and productivity growth of banks in GCC countries. International Journal of Business, 12(4), 471-487.

Ash, R. (1988). Job analysis in the world of work. In S. Gael (Ed.), The Job Analysis Handbook for Business (pp. 3-13). New York: John Wiley and Sons.

Barnes-Nelson, J. (1996). The boundaryless organization: Implications for job analysis, recruitment, and selection. Human Resource Planning, 20, 39-49.

Bassman, E. (1990). Strategic use of environmental scanning data. In M. London, E. Bassman, \& J. Fernandez (Eds.), Human resource forecasting and strategy development. New York: Quorum Books.

Beatty, R., Coleman, S., \& Schneier, C. (1988). In S. Gael (Ed.), The job analysis handbook for business, industry, and government, vol. 1. New York: John Wiley and Sons.

Berwitz, C. (1988). The role of job analysis in achieving affirmative action. In S. Gael (Ed.), The job analysis handbook for business, industry, and government, vol. 1. New York: John Wiley and Sons.

Boxall, P., \& Purcell, J. (2000). Strategic human resource management: Where have we come from and where should we be going? International Journal of Management Reviews, 14(2), 183-203.

Brannick, M. T., \& Levine, E. L. (2002).Job analysis. Methods, Research, and Applications for Human Resource Management in the New Millennium. California: Sage Publications, Inc. Campbell, C. (1989). Job analysis for industrial training. Journal of European Industrial Training, 13(2), 1-58.

Campion, M. (1994). Job analysis for the future. In M. Rumsey, C. Walker, \& J. Harris (Eds.), Personnel Selection and Classification. New Jersey: Lawrence Erlbaum Associates Publishers.

Camuffo, A., \& Costa, G. (1993). Strategic human resource management. Sloan Management Review, 59-67 Winter.

Carless, S. A. (2007). Graduate recruitment and selection in Australia. International Journal of Selection and Assessment, 15(2), 153-166.

Carson, K. P., \& Stewart, G. L. (1996). Job analysis and the sociotechnical approach to Q quality: A critical examination. Journal of Quality Management, 1(1), 49-65.

Catano, V., Cronshaw, S., Wiesner, W., Hackett, R., \& Methot, L. (1997). Recruitment and selection in Canada. Toronto: ITP Press.

Clifford, J. (1994). Job analysis: Why do it, and how it should be done? Public Personnel Management, 23(2), 321-340.

Colbert, B. (2004). The complex resource-based view: Implications for theory and practice in strategic human resource management. Academy of Management Review, 29(3), 341-358.

Cooke, R., \& Armstrong, M. (1990). The search for strategic HRM. Personnel management, 22(12), 30-33.

Cronshaw, S. (1998). Job analysis: Changing nature of work. Canadian Psychology, 39(1/2), 5-13.

Cronshaw, S., \& Schalm, R. (1995). Challenging the assumptions of strategic job analysis. University of Guelph Working Paper.

Davis, L., \& Wacker, G. (1988). Job design. In S. Gael (Ed.), The job analysis handbook for business, industry, and govermment, vol. 1. New York: John Wiley and Sons.

Denka, A. (1994). Achieve better management through better staffing. Managing Office Technology, 39(3), 10-15.

Dierdorff, E. C., \& Wilson, M. A. (2005). A meta-analysis of job analysis reliability. Journal of Applied Psychology, 88(4), 635-646.

Drucker, P. (1987). Workers' hands bound by tradition. Wall Street Journal, Aug. 2, p.18.

Dyer, L. (1985). Strategic human resources management and planning. In K. Rowland, \& G. Ferris (Eds.), Research in Personnel and Human Resources Management, vol. 3. (pp. 1-30).

Eppink, D. (1978). Planning for strategic flexibility. Long Range Planning, 11(4).

Ethridge, G., Rodgers, R. A., \& Fabian, E. S. (2007). Emerging roles, functions, specialty areas, and employment settings for contemporary rehabilitation practice. Journal of Applied Rehabilitation Counseling, 38(4), 27-33.

Evans, P. (1986). The strategic outcomes of human resource management. Human Resource Management, 25, 149-167.

Fisher, C. (1989). Current and recurrent in HRM. Journal of Management, 15(2), 157-180.

Fossum, J. (1984). Strategic issues in labor relations. In C. Fombrum, N. Tichy, \& M. Devanna (Eds.), Strategic Human Resource Management. New York: John Wiley and Sons.

Foulkes, F. (1986). Strategic Human Resources Management. New Jersey: Prentice-Hall.

Gael, S. (1988a). Preface. In S. Gael (Ed.), The job analysis handbook for business, industry and government, vol. 1. New York: John Wiley and Sons.

Gael, S. (1988b). Job descriptions. In S. Gael (Ed.), The job analysis handbook for business, industry, and government, vol. 1. New York: John Wiley and Sons.

Gatewood, R., \& Feild, H. (1994). Human resource selection. Orlando, FL: The Dryden Press. 
Ghorpade, J., \& Atchison, T. (1980). The concept of job analysis: A review and some suggestions. Public Personnel Management, 9, 134-144.

Guion, R. (1993). The need for change: Six persistent themes. In N. Schmitt, W. Borman, \& Associates (Eds.), Personnel selection in organizations San Francisco: JoseyBass Publishers.

Hammer, L. B., \& Barbera, K. M. (1997). Toward an integration of alternative work. Human Resource Planning, 20(2), 28-36.

Harrigan, K. (1985). Strategic flexibility: A management guide for changing times. Lexington, MA: Lexingotn Books.

Harvey, R. (1991). Job analysis. In M. Dunnette \& L. Gough (Eds.), Handbook for industrial and organizational psychology, vol. 2. California: Consulting Psychologists Press.

Harvey, R. J., \& Wilson, M. (2000). Yes Virginia, there is an objective reality in job analysis. Journal of Organizational Behaviour, 21, 829-854.

Henderson, R. (1988). Job evaluation, classification and pay. In S. Gael (Ed.), The job analysis handbook for business, industry, and government, vol. 1. New York: John Wiley and Sons.

Heneman, R. L. (2002). Strategic Reward Management. Connecticut: Information Age Publishing.

Hills, F. (1981). Job relatedness vs. adverse impact in personnel decision making. In R. Schuler, J. McFillen, \& D. Dalton (Eds.), Applied readings in personnel and human resource management. New York: West Publishing Company.

Honoree, A. L., Wyld, D. C., \& Juban, R. L. (2005). A step-by-step model for employers to comply with the Fairplay Overtime Initiative under the Fair Labor Standards Act (FLSA). Equal Opportunities International, 24(2), 54-66.

Ilgen, D. (1994). Jobs and roles: Accepting and coping with the changing structure of organizations. In M. Rumsey, C. Walker, \& J. Harris (Eds.), Personnel selection and classification. New Jersey: Lawrence Erlbaum Associates Publishers.

Ilgen, D., \& Hollenbeck, J. (1991). The structure of work: Jobs and roles. In M. Dunnette, \& L. Hough (Eds.), Handbook of industrial and organizational psychology, vol. 2. (pp. 165-208)

Jeanneret, R. (1991). Analyzing non-management jobs: An overview. In J. Jones, B. Steffy, \& D. Bray (Eds.), Applying psychology in business. Toronto: Lexington Books. Jenkins, M., \& Griffith, R. (2004). Using personality constructs to predict performance: Narrow or broad bandwidth. Journal of Business and Psychology, 19(2), 255-269. Jones, S. D., \& Schilling, D. J. (2000). Measuring team performance: A step-by-step, customizable approach for managers, facilitators, and team leaders. San Francisco: Jossey-Bass. Kerr, J., \& Jackofsky, E. (1989). Aligning managers with strategy: Management development versus selection. Strategic Management Journal, 10, 157-170.

Kochan, T. \& Weinstein, M. (1994). Recent developments in U.S. industrial relations. British Journal of Industrial Relations, 32(4), 483-504.

Konczak, L. J. (2007). Using individual assessments in the workplace: A practical guide for HR professionals, trainers, and managers. Personnel Psychology, 60 (3), 793-796.

Kydd, C., \& Oppenheim, L. (1990). Using human resource management to enhance competitiveness: Lessons from four excellent companies. Human Resource Management, 29(2), 145-166

Landry, B. J. L., Mahesh, S., \& Hartman, S. (2005). The changing nature of work in the age of e-business. Journal of Organizational Change Management, 18(2), 132-144.

Latham, G., \& Fry, L. (1988). Measuring and appraising employee performance. In S. Gael (Ed.), The job analysis handbook for business, industry, and government, vol. 1. New York: John Wiley and Sons.

Lawler, E. (1984). The strategic design of reward systems. In C. Fombrum, N. Tichy, \& M. Devanna(Eds.),Strategic human resource management. New York: John Wiley and Sons.

Lengnick-Hall, C., \& Lengnick-Hall, M. (1988). Strategic human resource management, a review of the literature and proposed typology. Academy of Management Review, 13, 454-470.

Levine, E. (1983). Everything you always wanted to know about job analysis. Florida: Mariner Publishing Co. Inc

The Delphi method: Methods and applications. Linstone, H., \& Turoff, M. (Eds.). (1975). R Reading MA: Addison-Wesley.

London, M. (1988). Change agents: New roles and innovation strategies for human resource professionals. San Francisco: Jossey-Bass Publishers.

Lund, R., \& Hansen, J. (1986). Keeping America at work: Strategies for employing the new technologies. New York: Wiley.

Manzini, A., \& Gridley, J. (1986). Integrating human resources and strategic business planning. New York: Amacom.

Marjchzak, A., \& Klein, K. (1987). An open system approach to the organizational effects of computer-automated technology. Journal of Business and Psychology, 2, 8-26.

May, K. (1996). Work in the 21st century: Implications for job analysis. The Industrial Organizational Psychologist, 33(4), 98-100.

McCormick, E. (1976). Job and task analysis. In M. Dunnette (Ed.), Handbook of Industrial and Organizational Psychology, vol. 1. (pp. 651-695).

McCune, J., Beatty, R., \& Montagno, R. (1988). Downsizing: Practices in manufacturing firms. Human Resource Management, 27, 145-161.

Meshoulam, I., \& Baird, L. (1987). Proactive human resource management. Human Resource Management, 26, 483-502.

Miles, R., \& Snow, C. (1978). Organizational strategy, structure and process. New-York: McGraw-Hill.

Miles, R. E., Snow, C. C., Meyer, A. D., \& Coleman, H., Jr. (1978). Organizational strategy, structure, and process. Academy of Management Review, 3(3), 546-562.

Mintroff, I. (1987). Business not as usual. San Francisco: Josey-Bass.

Mintzberg, H. (1987, July-Aug..). Crafting strategy. Harvard Business Review, 4.

Mirabile, R. J. (1990). The power of job analysis. Training, 27(4), 70-74.

Mitchell, J., Ruck, H., \& Driskill, W. (1988). Task-based training program development. In S. Gael (Ed.), The job analysis handbook for business, industry and government, vol. 1. New York: John Wiley and Sons.

Moravec, M., Juliff, R., \& Hesler, K. (1995). Partnerships help a company manager performance. Personnel Journal, 74(1), 104-108.

Morgan, R., \& Smith, J. (1996). Staffing the new workplace. Chicago, IL: CCH Incorporated.

Nelson, J. B. (1997). The boundaryless organization: Implications for job analysis, recruitment, and selection. Human Resource Planning, 20(4), 39-40.

Nieva, V. F., Fleishman, E. A., \& Reick, A. (1978). Team Dimensions: Their identity, their measurement and their relationships (Contract No. DAHC19-78-C-0001). Washington DC: Advanced Research Resources Organization.

Olian, J., \& Rynes, S. (1992). Making total quality management work. Human Resource Management, 30(3), 303-333.

Oswald, F. L. (2003). Job analysis: Methods, research, and applications for human resource management in the new millennium. Personnel Psychology, 56(3), 800-802.

Palmer, H., \& Valet, W. (2001). Job analysis: Targeting needed skills. Employment relations today, 28(3), 85-91.

Pffefer, J. (1994). Competitive Advantage Through People. Cambridge, Mass.: Harvard University Press.

Porter, M. (1980). Competitive strategy: Techniques for analyzing industries and competitors. New York: Free Press.

Porter, M. (1985). Competitive advantage. New York: Free Press.

Prien, K. O., Prien, E. P., \& Wooten, W. (2003). Interrater reliability in job analysis: Differences in strategy and perspective. Public Personnel Management, 32(1), 125-141.

Primoff, E., \& Fine, S. (1988). A history of job analysis. In S. Gael (Ed.), The job analysis handbook for business, industry and government, vol. 1. New York: John Wiley and Sons.

Ragburam, S., \& Arvey, R. D. (1994). Business strategy links with staffing and training practices. Human resource Planning, 17(3), 55-73.

Rice, M. P., OConnor, G. C., \& Pierantozzi, R. (2008). Implementing a learning plan to counter project uncertainty. MIT Sloan Management Review, 49(2), 54-62.

Sanchez, J. (1994). From documentation to innovation: Reshaping job analysis to meet emerging business needs. Human Resource Management Review, 4(1), 51-74.

Sanchez, J. I., \& Levine, E. L. (1999). Is job analysis dead, misunderstood, or both? In A. I. Kraut, \& A. K. Korman (Eds.), Evolving Practices in Human Resource Management. Responses to a Changing World of Work San Francisco: Jossey-Bass Publishers.

Sanchez, J. I., \& Levine, E. L. (2000). Accuracy or consequential validity: Which is the better standard for job analysis data? Journal of Organizational Behavior, 21, $809-818$

Schneider, B., \& Konz, A. (1989). Strategic job analysis. Human Resource Management, 28(1), 51-63.

Schofield, P. (1993). Improving the candidate-job match. Personnel Management, 25(2), 69.

Schrenk, L. (1988). Environmental scanning. In L. Dyer (Ed.), Human resource management: Evolving roles and responsibilities. BNA: Washington.

Schuler, R., \& Jackson, S. (1987). Linking competitive strategies and human resources management practices. Academy of Management Executive, 1, 207-219.

Sheridan, J. (1990). Forecasts and projections. In M. London, E. Bassman, \& J. Fernandez (Eds.), Human resource forecasting and strategy development. New York: Quorum Books.

Shippmann, J., Ash, R., Battista, M., Carr, L., Eyde, L., Hesketh, B., et al. (2000). The practice of competency modelling. Personnel Psychology, 53, 703-740.

Siddique, C. M. (2004). Job analysis: A strategic human resource management practice. International Journal of Human Resource Management, 15(1), $219-244$.

Simola, S. K., Taggar, S., \& Smith, G. W. (2007). The employment selection interview: Disparity among research-based recommendations, current practices and what matters to human rights tribunals. Canadian Journal of Administrative Sciences, 24(1), 30-44. 
Snell, S., \& Dean, J. (1994). Strategic compensation for integrated manufacturing: The moderating effects of jobs and organizational inertia. Academy of Management Journal, 37(5), 1109-1140.

Snow, C., \& Snell, S. (1993). Staffing as strategy. In N. Schmitt, W. Borman, \& Associates (Eds.), Personnel selection in organizations. San Francisco: Josey-Bass. Sparks, C. (1988). Legal basis for job analysis. In S. Gael (Ed.), The job analysis handbook for business, industry and government, vol. 1. New York: John Wiley and Sons. Stewart, G. L., \& Carson, K. P. (1997). Moving beyond the mechanistic model: An alternative approach to staffing for contemporary organizations. Human Resource Management Review, 7(2), 157-184.

Swezney, R., \& Salas, E. (1992). Teams: Their training and performance. Norwood, NJ: Ablex.

Taber, T., \& Peters, T. (1991). Assessing the completeness of a job analysis procedure. Journal of Organizational Behaviour, 12(7), 581-593.

Thacker, R. (1990). Affirmative action after the Supreme Court's 1988-1989 term: What employers need to know. Employee Relations Today, 17(2), 139-144.

Tichy, N. (1985). Foreward: Strategic planning and human resource management. Human Resource Management, 26.

Varca, P., \& Pattison, P. (1993). Evidentiary standards employment discrimination: A view toward the future. Personnel Psychology, 46, $237-258$.

Veres, J., Lahey, M., \& Buckly, R. (1987). A practical rationale for using multi method job analysis. Public Personnel Management, 16(2), 153-157.

Voskuijl, O. F. (2005). Job Analysis: Current and future perspectives. In A. Evers, N. Anderson, \& 0. Voskuijl (Eds.), The Blackwell Handbook of Personnel Selection Oxford: Blackwell Publishing.

Walker, J. (1992). Human resource strategy. New York: McGraw-Hill.

Weinberger, T. (1989). Modelling job rates to reflect the values of changing business strategies. Journal of Compensation and Benefits, 4(5), 278-283.

Weinberger, T. E. (2007). The pay-for-strategic value method: A tool for compensation professionals in the outsourced environment. Compensation and Benefits Review, 39(1), 40-49.

Wernimont, P. (1988). Recruitment, selection and placement. In S. Gael (Ed.), The job analysis handbook for business, industry, and government, vol. 1. New York: John Wiley and Sons.

Wiesdanger, B. (1994). The state of the unions. Journal of Business Strategy, 15(2), 52-56.

Wiesner, W. (1992). Development of employment interview technology: Implications for innovative organizations.: MGD School of Business, McMaster University Working Paper.

Wilde, E. (1993). Finding the right person for the job. Management Services, 37(3), 24-26.

Wooten, W. (1993). Using knowledge, skill and ability (KSA) data to identify career pathing opportunities: An application of job analysis to internal manpower training. Public Personnel Management, 22(4), 551-563.

Wright, P., \& McMahan, G. (1992). Theoretical perspectives for strategic human resource management. Jourmal of Management, 18(2), 295-320.

Wright, P., \& Snell, S. (1991). Toward an integrative view of strategic human resource management. Human Resource Management Review, 1, $203-225$.

Wright, P., \& Snell, S. (1988). Toward a unifying framework for exploring fit and flexibility in strategic human resource management. Academy of Management Review, 23(4), 756-772.

Young, S. (1992). A framework for successful adoption and performance of Japanese manufacturing practices in the U.S. Academy of Management Review, 17,677-700. 